\title{
Naujoji valstybės tarnautojų atranka: pirmieji rezultatai ir ižvvalgos
}

\author{
Rasa Tumènè \\ Valstybès tarnybos departamentas \\ Labdariu g. 8, Vilnius \\ Irena Žukauskaitè \\ Valstybès tarnybos departamentas \\ Labdariu g. 8, Vilnius \\ Žilvinas Židonis \\ Mykolo Romerio universitetas \\ Valakupiug. 5, Vilnius \\ doi:10.13165/VPA-14-13-4-05
}

\begin{abstract}
Anotacija. Valstybès tarnautoju atrankos profesionalumas ir skaidrumas yra vienas iš pagrindiniu faktoriu, lemiančiu kokybiška žmogiškuju ištekliu valdyma bei viešuju paslaugu teikima. Naujas $2013 \mathrm{~m}$. birželio mènesị ịsigaliojęs valstybès tarnautoju atrankos modelis atspindi bendra Lietuvos viešojo valdymo modernizavimo krypti, kuri teikia pirmenybe vadybiniams valdymo metodams. 2013-2014 metais atliktos vadovu, idarbinusiu valstybès tarnautojus pagal naujaja tvarka, ir valstybès tarnautoju, priimtu pagal naujaja atrankos tvarka, apklausos duomenu analizè rodo, kad dèl padidejjusio atrankos skaidrumo, objektyvumo, procedūru paprastumo bei viešumo naujas modelis iš esmès yra vertinamas teigiamai.
\end{abstract}

Raktažodžiai: valstybès tarnyba, atranka, naujoji viešoji vadyba.

Keywords: civil service, selection and recruitment, New Public Management. 


\section{Ivadas}

Nauji ekonominiai, socialiniai ir geopolitiniai pokyčiai, vykstantys tiek šalies viduje, tiek ir už jos ribų, kelia vis sudètingesnius valstybès valdymo iššūkius. Viena iš pagrindinių Lietuvos viešojo administravimo problemų yra nepakankamai moderni, lanksti ir ị pokyčius orientuota valstybès tarnyba. Kalbama ne tiek apie demokratijos, kaip esminio modernios Vakarų pasaulio valstybès atributo stiprinimą, kiek apie gebejjimą profesionaliai valdyti valstybę, arba, kitaip tariant, viešosios biurokratijos kokybę. Europos Komisijos valdymo kokybės ataskaitoje (angl. quality of governance) pažymima, kad „nèra jokios abejonès, jog kokybiškos biurokratijos ir valstybės tarnybos sistema turi išskirtinę reikšmę šalies ekonomikos augimui, pagrindinių viešųjų paslaugų teikimui bei teisètumo ir piliečių pasitikèjimo kūrimui““ [17, p. 83].

Siekiant užtikrinti valdymo kokybę ir modernizuoti valstybès tarnybą, vis daugiau dèmesio yra skiriama valstybès tarnautojų atrankos profesionalumui ir skaidrumui didinti. $2013 \mathrm{~m}$. birželio mènesị ịsigaliojusi naujoji valstybès tarnautojų atranka - ilgai brandintas ir kryptingai igyvendintas pokytis, kuriuo siekta modernizuoti valstybès tarnybą, padaryti ją patrauklesnę ir skaidresnę visuomenei, išspręsti įsisenejjusias problemas. Apie atrankos viešajame sektoriuje problemas kalbama jau seniai. Neatsitiktinai Vyriausybės 2006-2008 metų programoje buvo minima, kad būtina „tobulinti valstybės tarnautojų atranką ir tarnybinès veiklos vertinimo procedūras. Išgyvendinti protekcionizmą priimant ị valstybės tarnybą" [14, p. 166]. Atrankų skaidrumo trūkumas, nelanksti atrankos sistema, siauras pretendento vertinamų charakteristikų spektras, manipuliavimas reikalavimais kandidatams ir kitos problemos buvo minimos ir S. Pivoro [23] atliktoje analizejje. Skaidrumo valstybės tarnyboje aspektą tyre ir Specialiųjų tyrimų tarnyba [1].

$2013 \mathrm{~m}$. birželio $1 \mathrm{~d}$. ịsigaliojo Valstybės tarnybos įstatymo pakeitimai, kurie įtvirtino iš dalies centralizuotą valstybès tarnautojų atranką - I atrankos etapas (bendrųjų gebejjimų ir, jei pretenduojama užimti vadovaujančias pareigas, vadovavimo gebejjimų patikrinimas centralizuotai vykdomas Valstybės tarnybos departamente), II etapas - pokalbis įstaigoje (kurio metu gali būti pateikiama ir praktiné užduotis). Naujoji atrankos sistema pakeitè iki tol daugiau nei 10 metų galiojusią teisès aktų žinių patikrinimo tvarką.

Šio straipsnio tikslas yra išanalizuoti valstybès tarnautojų atrankos profesionalumo ir skaidrumo aspektus naujosios valstybės tarnautojų atrankos kontekste. Straipsnis paremtas asmenų, sprendusių kompiuterinį bendrųjų gebejjimų testą, asmenų, priimtų ị valstybės tarnautojo pareigas, ir priimtų valstybės tarnautojų tiesioginių vadovų apklausos duomenimis, taip pat dokumentų ir statistinių duomenų analize, teisinio reglamentavimo vertinimu.

\section{Valstybės tarnautojų atranka viešojo valdymo pokyčių kontekste}

Valstybės tarnautojų atrankos modeliai ir igyvendinimo būdai yra viešojo valdymo reformų dalis. Kaip pabrèžiama šaltiniuose [22], viešojo valdymo pokyčiu 
kryptis ir turinys priklauso nuo šalyje vyraujančios administravimo tradicijos, kurią lemia šalies valdymo struktūrose vyraujančios vertybės ir nuostatos. Tokie pokyčiai kaip „tarnautojo darbo rezultatų vertinimas ir apmokejjimo pagal rezultatus nustatymas" sẻkmingai prigyja šalyse, kuriose vyrauja individualistinès, konkurenciją ir asmeninę sèkmę pabrěžiančios vertybès (pvz., Didžiojoje Britanijoje). Kitu šalių, pavyzdžiui, Vokietijos, Prancūzijos, valstybės tarnybose darbuotojų tarpusavio santykiai yra hierarchiški, vyrauja „pareigybės kultas“ ir griežta subordinacija.

G. Petersas [22] skiria keturias pagrindines Vakarų Europos ir Šiaurès Amerikos viešojo administravimo tradicijas: anglosaksų (minimalios valstybės), kontinentines vokišką (organinę) ir prancūzišką (Napoleono) bei skandinavišką (anglosaksų ir vokiškos mišinys). Lietuva priklauso kontinentinès administracinès tradicijos sričiai, todèl reiktų išsamiau aptarti šios tradicijos bruožus, jų poveikị valstybės tarnybai ir naujosios viešosios vadybos, kaip anglosaksų tradicijos produkto, itaką kontinentinio tipo valstybès tarnybos sistemai.

Vokiška (organinè) administracinė tradicija valstybę traktuoja kaip vieną nedalomą „organizmą“. G. Hėgelis [10] (p. 414) teigia: „Pagrindinè politinès valstybės apibrèžtis yra substanciali vienybė kaip jos momentų idealybė... Ši momentų idealybė yra tolydi organinio kūno gyvybei: ji yra kiekviename taške, visuose taškuose yra tik viena gyvybe ir pasipriešinimo jai nèra.“ Valstybės tarnyba yra „valstybės organizmo" dalis, todèl bet kokie pokyčiai turi būti evoliuciniai ir vykdomi laipsniškai. Antra, organine paradigma teigia, kad valstybės tarnautojai yra valstybės valios vykdytojai. Kontinentinè administracinè tradicija valstybę iškelia aukščiau piliečių susitarimo. G. Hėgelis [10] teigia, kad valstybè nėra atskirų žmonių sutartis, o objektyvi valia, nesvarbu, ar atskiras žmogus ją pažįsta, ar ne. P. Leonas [13] pastebi, kad, G. Hėgelio supratimu, valstybè nèra dirbtinis dalykas, ji nesukurta susitarimo pagrindu, o valstybės tarnyba yra organinė valstybès dalis. Toks požiūris ị valstybę suponuoja atitinkamus reikalavimus, keliamus kandidatams ị valstybès tarnybą. Būsimas valstybès tarnautojas visų pirma yra traktuojamas kaip valstybès valios išraiškos igyvendintojas, todèl pagrindinès šioje tarnyboje reikalingos kompetencijos yra teisinès žinios, nes anot G. Hėgelio, valstybès objektyvi valia pasireiškia per teisès aktus. Antra, teisès aktų išmanymas ir jų vykdymo kompetencija yra vienintelis būdas, kuris apriboja valstybės tarnautojų savivalę, užtikrina valstybès tarnybos profesionalumą ir veiklos efektyvumą. Tai vadinamasis véberinis (sukurtas Maxo Weberio) valstybès tarnybos modelis, kuris 1999 metais Lietuvoje buvo formaliai įtvirtintas priemus Valstybės tarnybos įstatymą. Kaip pažymi S. Pivoras [23], kadangi Valstybės tarnybos ịstatymo rengejjus konsultavo ES ekspertai, administracinès teisès specialistai, valstybès tarnyba susiformavo kaip administracinès teisès institutas. Toks valstybės tarnybos karjeros modelis turi ne tik anksčiau aptartų privalumų, bet ir rimtų trūkumų. Griežtas politikos ir administravimo atskyrimas sumažino valdininkų kontrolès galimybes ir biurokratija evoliucionavo ị uždarą struktūrą, kuri geba efektyviai „gintis“ nuo bet kokių jai nepalankių pokyčių. Todèl jau 2002 metais buvo priimta nauja Valstybės tarnybos istatymo redakcija, leidusi karjeros modelị derinti su postų sistema. Pavyzdžiui, 
priimant buvo panaikintas bandomasis laikotarpis, anksčiau privalomas pradedantiems karjerą valstybės tarnyboje, taip pat atsisakyta darbo patirties valstybės tarnyboje reikalavimo priimant ị aukštesnes karjeros tarnautojo pareigybes.

Naujo požiūrio ir kardinalių reformų poreikị suponavo 2008 metais prasidèjusi ekonomikos krizé, kuri kaip tik sutapo su naujos penkioliktosios Vyriausybės kadencijos pradžia. Kaip pažymi V. Nakrošis [18], penkioliktosios A. Kubiliaus Vyriausybės viešojo valdymo reformų turinys buvo pagrịstas vadybiniu požiūriu, vyrauja naujosios viešosios vadybos NVV) doktrinos bruožai. NVV susiformavo XX a. aštuntajame dešimtmetyje anglosaksų šalyse - Naujoje Zelandijoje, Australijoje, Jungtinejje Karalysteje, Kanadoje, JAV. Anglosaksų viešosios biurokratijos tradicija į valstybès tarnybą žvelgia instrumentiškai, kaip į vieną iš valstybinio valdymo objektų. Šią filosofiją gerai atspindi T. Gaeblerio ir D. Osborne’o propaguojama „vyriausybès perkūrimo“ idèja [20]. Šių autorių požiūriu [20], valstybės tarnyba yra viena iš paslaugų teikejjų. Kiti teikẻjai gali būti tiek privačios, tiek nevyriausybinès organizacijos. Viešosios politikos vadovai turi turèti galimybę „išsirinkti prieš perkant“ (angl. to shop around) geriausią paslaugų teikejją [20]. „Valdžios perkūrimo“ koncepcija atstovauja vienam iš pačių radikaliausių požiūrių i valstybès tarnybą. Minèti autoriai gana kategoriškai pareiškia, kad šiuolaikinèje visuomeneje valstybės tarnybos sistema yra tikras kliuvinys, nes vadybininkai (viešosios politikos formuotojai) negali efektyviai vadovauti valstybės tarnybos sistemos personalui [20]. Todèl turi būti iš esmès keičiami valstybès tarnautojų prièmimo, motyvavimo bei atleidimo principai. Plačiai paplitusi nuomonè, kad kontinentinès tradicijos valstybės tarnybos modelis pabrèžia biurokratų politinị neutralumą, tačiau pati organinès valstybès koncepcija tiek politikus, tiek biurokratus traktuoja kaip vientiso „organizmo“ dalis. „Vyriausybės perkūrimo“ paradigma giežtai skiria viešosios politikos valdymą (angl. policy management) ir viešųjų paslaugų teikimą. Todèl anglosaksų administracinè tradicija ị valstybės tarnybos pokyčius žiūri radikaliau ir pabréžia tokius momentus kaip paslaugų teikèjų konkurencija ir atskaitomybė už veiklos kokybės užtikrinimą. Kaip tvirtina mokslininkai, paslaugų teikéjas žino, kad dèl blogos kokybės gali būti nutraukta sutartis, o valstybės tarnautojas žino, kad su juo taip pasielgti niekas negali [20].

Tarp penkioliktosios Vyriausybės prioritetų buvo numatyti ị rezultatus orientuoto valstybės tarnybos modernizavimo modelio principai. Idèjų buvo semtasi iš NVV doktrinos, kuri skelbia, kad reikia „leisti vadybininkams valdyti“. „Leidimas valdyti" reiškia ne tik ịgaliojimų suteikimą valstybės tarnautojams (arba pagal darbo sutartis dirbantiesiems), bet ir reikalavimą, kad tokie darbuotojai turètų vadybinių kompetencijų, o valstybės tarnybos karjeros planavimo sistema užtikrintų šių kompetencijų igijimą ir ugdymą.

\section{Naujoji valstybės tarnautojų atranka}

Naujoji valstybės tarnautojų atrankos sistema buvo diegiama atsižvelgiant $i$ kitose šalyse pasiteisinusią atrankos praktiką, technologines naujoves, moder- 
nius atrankos metodus. Vienas didžiausių pokyčiu esamoje - sprendimas atranką iš dalies centralizuoti, t. y. pirmaji atrankos etapą vykdyti Valstybès tarnybos departamente. Centralizuotos atrankos modelis taikomas Belgijoje, Airijoje, taip pat Europos Sajungos institucijose (EPSO - Europos personalo atrankos tarnyboje (angl. European Personnel Selection Office), iš dalies centralizuotas - Austrijoje, Prancūzijoje, Maltoje, Rumunijoje, Didžiojoje Britanijoje, Vengrijoje, Olandijoje [12].

Remiantis Valstybės tarnautojų atrankos tobulinimo koncepcija [28], atrankos centralizavimo stiprybės yra šios:

- Taikant unifikuotus pretendentų registravimo ir informavimo būdus užtikrinamas didesnis valstybės tarnautojų atrankos skaidrumas ir pretendentų galimybès gauti visą reikalingą informaciją.

- Centrinè įstaiga su valstybès tarnautoją i pareigas priimančia ịstaiga suderina kompetencijas, metodus, atrankos etapų skaičiu ir kitus aspektus. Toks atrankos vykdymas leidžia suderinti valstybės tarnautoją i pareigas priimančios ịstaigos poreikius su atranką vykdančios ịstaigos galimybėmis.

- Taikomi kokybiškesni atrankos ị valstybės tarnybą metodai, kurie leidžia atrinkti tinkamiausius pretendentus.

- Centralizuota valstybės tarnautojų atranka sudaro galimybes centrinei įstaigai kaupti valstybės tarnautojų atrankos patirtị bei sudaro prielaidas tapti kompetencijos centru.

- Centrinejje įstaigoje atsiranda galimybė koncentruoti išteklius ir kompetencijas, užtikrinant valstybės tarnautojų atrankos kokybę, profesionalumą ir efektyvumą.

- Galimybė greitai ir efektyviai atlikti tam tikrus atrankos procesus: patikrinti pretendentų bendruosius gebejjimus, formalų pretendentų atitikimą keliamiems reikalavimams, informuoti suinteresuotus asmenis apie laisvas pareigybes valstybės tarnyboje, kaupti istorinius ir statistinius duomenis apie atrankų vykdymą.

- Galimybė plèsti valstybės tarnautojų atrankos apimtį, įtraukiant ir statutinius valstybės tarnautojus arba darbuotojus, dirbančius pagal darbo sutartis.

Be abejo, ši sistema turi ir trūkumų. Centralizacijos atveju kyla tarpinstitucinio koordinavimo problema - centrinè įstaiga per daug nutolsta nuo konkursus inicijuojančių ịstaigų problemų, neįsigilinama ị ịstaigos problematiką taikant unifikuotus sprendimus [27]. Taip pat teigiama, kad jei ịstaiga yra maža, tokia atranka kainuoja brangiau, yra ne tokia lanksti, sudètingiau įvertinti darbuotojų tinkamumą konkrečiai darbo vietai, ne toks svarbus tiesioginio vadovo vaidmuo [12]. Čia išvardintas problemas valstybės tarnautojų atrankoje leidžia eliminuoti dalinė proceso centralizacija, kai atsakomybė už tinkamo kandidato parinkimą tenka dviem įstaigoms - centrinei ir tiesiogiai ieškančiai darbuotojo.

Pirmajame naujos valstybės tarnautojų atrankos etape pretendentai ị valstybès tarnybą turi išlaikyti bendrųjų gebejjimų testą, susidedantị iš dviejų dalių: bendrųjų mąstymo gebejjimų ir bendrųjų kompetencijų. Būtent testo turinio pasikeitimas 
yra dar vienas didelis pokytis naujojoje atrankos sistemoje. Testai, kaip atrankos priemonè, yra plačiai taikomi tiek privačiame, tiek viešajame sektoriuje ir leidžia atskirti testo metu parodžiusius gebejjimus ir kompetencijas kandidatus. Tačiau prieš tai galiojusios atrankos problema slypejo tiek paties testo turinyje, tiek jo taikyme.

Iki naujos atrankos įsigaliojimo testą sudarẻ 100 klausimų, kuriais tikrinamos vien tik teisès aktų žinios. Be to, dalis klausimų buvo viešai prieinami žiniasklaidoje, todèl jų išmokimas atmintinai ši atrankos etapą paversdavo formalumu. Tyrimai rodo [15], kad žinių testų prognostinis validumas yra didelis, kai jis tiesiogiai susijęs su būsimo darbo specifika. Taigi, iškilo būtinybė ieškoti visų valstybės tarnautojų atrankai tinkančio testo formų.

Daugelyje Europos Sąjungos šalių, pvz., Didžiojoje Britanijoje, Austrijoje, Belgijoje, Estijoje, Suomijoje bei EPSO valstybėse, tarnautojų atrankoje naudojami bendrujų gebėjimų testai [29]. Portugalijoje, Belgijoje, Rumunijoje testais yra vertinamos pretendentų i valstybès tarnybą kompetencijos. Airijoje, Danijoje ir Austrijoje asmenys, norintys tapti valstybès tarnautojais, pildo asmenybės testus, yra sudaromi jų profiliai ir pagal šiuos rezultatus pasirenkami geriausi kandidatai. Lietuvoje nuspręsta vertinti pretendentų bendruosius mąstymo gebejjimus, nes testu yra matuojamas pretendento gebejjimas mąstyti, rasti dėsningumus, spręsti užduotis, su kuriomis susiduriama pirmą kartą, atidžiai stebėti instrukcijas, rasti reikiamą informaciją. Bendrųų gebėjimų testas yra viena iš efektyviausių darbo atlikimo prognozavimo priemonių [26]. Asmenys, kurie gerai sprendžia bendrųjų gebėjimų testus, dažniausiai igyja daugiau darbui reikalingos informacijos, priima geresnius sprendimus, sẻkmingai sprendžia problemas, tinkamai reaguoja ị naujas ir sudètingas situacijas [5]. Taip pat, atsižvelgiant ị planuojamą diegti kompetencijų modelị valstybės tarnyboje, nuspręsta vertinti pretendentų bendrąsias kompetencijas ir užtikrinti, kad ị valstybės tarnybą būtų priimami bent minimalius kompetencijų reikalavimus atitinkantys asmenys.

Atskiro paminejjimo vertas centralizuotai pradètas vykdyti vadovavimo gebejjimų tikrinimas. Būtent viduriniosios grandies stiprinimas tampa prioritetu [7], nes problemų sprendimų kokybė ne tik strateginiu, bet ir taktiniu lygiu lemia sveiką valstybės tarnybos organizmo funkcionavimą. Lietuvoje, kaip ir Kipre, Portugalijoje ar Maltoje, vadovavimų gebejjimams tikrinti pasirinktas pokalbio metodas. Pusiau struktūruotas pokalbis yra vienas patikimiausių atrankos instrumentų, o jị derinant kartu su kognityviniais testais prognostinis validumas išauga nuo 0,51 iki 0,63 [5]. Vertinimo objektyvumą lemia ne tik pretendento turimos patirties ir žinių atskleidimas, bet ir atranką vykdančių ekspertų profesionalumas.

Dar vienas pokytis, kuris paveikè visus asmenis, pretenduojančius tapti valstybès tarnautojais, - tai viso proceso administravimo perkèlimas ì elektroninę erdvę (www.testavimas.vtd.lt). Atsižvelgiant į Europos šalių patirtị, buvo sukurta Atrankos modulio savitarnos sistema. Ja naudodamasis asmuo kandidatuoja i valstybės tarnybą. Nuo šiol:

- prašymų dalyvauti konkurse teikimas ir tikslinimas galimas 24 valandas per parą 7 dienas per savaitę iš bet kurio internetinę prieigą turinčio prietaiso; 
- yra galimybė registruotis online būdu laikyti bendrųjų gebèjimų bei anglų, vokiečių, prancūzų kalbų testus, atlikti vadovavimo gebẻjimų patikrinimą;

- testų ir vadovavimo gebejjimų patikrinimų rezultatų automatiškas susiejimas su pateiktais prašymais dalyvauti konkurse;

- yra galimybe elektroniniame segtuve saugoti pretenduoti ị valstybės tarnybą reikalingus dokumentus;

- paruoštos pagrindinių dokumentų elektroninès formos;

- pretendentai gali užsisakyti paskelbtų naujų konkursų / pakaitinių atrankų / testavimų prenumeratą.

Elektroninės konkursų ir pakaitinių valstybės tarnautojų atrankos administravimo (įskaitant dokumentų pateikimą) sistemos įdiegimas leido išspręsti dvi pagrindines problemas - pretendentams aplikavimas dèl darbo supaprastèjo, procedūra tapo prieinamesnè ir patrauklesnè, o įstaigoms ir Valstybès tarnybos departamentui buvo sudarytos sąlygos kaupti duomenis, juos analizuoti ir panaudoti konkursų ir pakaitinių valstybės tarnautojų atrankos procesams tobulinti. Kaip teigia autoriai [16], įdarbinimo procesas, vykstantis elektroninèje erdvejje, yra pranašesnis daugeliu aspektų, kurie vartotojų yra vertinami kaip patrauklūs: jis yra greitesnis, informatyvesnis (leidžia dèti nuorodas ị įstaigos puslapius), leidžia taupyti kartais sunkiai ižvelgiamus kaštus (Lietuvoje - pretendento pašto išlaidas ir pan.). Tai taip pat yra daug efektyvesnis būdas vertinant iš darbdavio pozicijos - duomenys kaupiami automatiškai, pateiktų prašymų nereikia spausdinti, rūpintis jų archyvavimu, duomenys lengvai apdorojami ir analizuojami. Be to, yra taupomi įstaigos, šiuo atveju valstybės, lěšos - nebereikia spausdinti skelbimų popieriniuose leidiniuose. Be to, leidžiant pateikti prašymą elektroniniu būdu sulaukiama daugiau pretendentų [6]. Nuo 2013 m. birželio 1 d. iki 2014 m. birželio 1 d. vidutiniškai ị vieną vietą pretenduoja 13 asmenų. Valstybès tarnybos departamento atliktos apklausos duomenimis, dauguma valstybès tarnyboje dirbančiu personalo darbuotojų sutinka, kad elektroninis prašymų administravimas sumažina darbo kaštus [30].

Nors dažniausiai yra kalbama apie elektroninio prašymų teikimo teikiamus privalumus, kiti autoriai nurodo ir minusus, pvz., galima pretendentų diskriminacija [6]. I šị trūkumą ypač svarbu atsižvelgti taikant elektroninę prašymų teikimo sistemą valstybiniame sektoriuje Lietuvoje, kadangi istatymų numatyta tvarka visiems piliečiams turi būti sudarytos vienodos sąlygos stoti ị valstybẻs tarnybą. Europos šalyse prašymų teikimas elektroniniu būdu bene labiausiai modernizuotas Belgijoje, kur nuo $2005 \mathrm{~m}$. liepos visi atviri konkursai vykdomi tik per SELOR administruojamą specializuotą informacinę sistemą Mano SELOR (pranc. Mon SELOR), skirtą elektroninei valstybės tarnautojų atrankai [28]. Analogiškas sistemas turi Airija, Olandija, EPSO.

Pokyčių diegiant naująją atrankos sistemą būta ir daugiau (pvz., atranką įstaigoje galima organizuoti kelias dienas), tačiau šiame straipsnyje apsiribosime respondentų nuomone ị jau pristatytus naujosios atrankos aspektus. 


\section{Profesionalios darbuotojų atrankos tendencijos - kandidatų reakcijos i atranką svarba}

Profesionali darbuotojų atranka yra suprantama kaip įvairiais metodais grịstas informacijos apie asmenį rinkimo ir ịvertinimo procesas, siekiant pateikti įdarbinimo pasiūlymą. Toks ịdarbinimo pasiūlymas gali būti pirma darbo pozicija naujam darbuotojui arba kita pozicija esamam darbuotojui. Atrankos procesas igyvendinamas atsižvelgiant ị tam tikras teisines ir aplinkos sąlygas bei organizacijos ir asmens interesus [3]. Iš organizacijos perspektyvos yra svarbu sudominti kandidatus darbo vieta ir organizacija, pritraukti geriausius kandidatus darbo rinkoje. Atrankos tikslas yra iš kandidatų grupès pasirinkti tuos kandidatus, kurie turi tinkamas žinias, gebejjimus, ịgūdžius ar kitus ypatumus, reikalingus sèkmingai atlikti veiklą. Manoma, kad siekiant geriau prognozuoti būsimo darbo rezultatus, turi būti taikomi patikimi ir validūs atrankos metodai [18-20].

Kandidatai teikia pirmenybę tiems atrankos metodams, kurie atrodo labiau susiję su darbu, teisingi ir objektyvūs [9]. Tyrimai rodo, kad interviu, darbo užduotys, žinių testai ir vertinimo centrai yra kandidatams priimtinesni negu bendrųjų kognityvinių gebejjimų testai, o pastarieji suvokiami kaip priimtinesni negu asmenybės klausimynai, asmeninių duomenų analizè ir grafologija [9; 24].

Praktikoje rekomenduojama parinkti atrankos metodus ir taikyti atrankos procedūras, siekiant formuoti teigiamą kandidatų nuomonę apie atranką $(4 ; 9)$. Igyvendinant valstybès tarnybos tarnautojų atrankos sistemos reformą Lietuvoje, buvo atsižvelgta ị tyrimų duomenis apie kandidatų reakcijas ị atranką ir pritaikyti kai kurie teigiamo kandidatų požiūrio formavimo ị atranką principai atrankos procedūrose:

- Standartizuotai vykdomas bendrųjų gebėjimų, bendrujų kompetencijų ir vadovavimo gebejjimų vertinimas.

- Atrankos metodų taikymas pagrịstas reikalavimais kandidatams, nustatytais pareigybių aprašymais.

- Testavimas vykdomas automatizuotu, kompiuteriniu būdu.

- Pokalbių metu laikomasi bendrujų gero pokalbio vedimo principų, tokių kaip aiškus pokalbio formatas, tinkamas klausimų pateikimas ir klausimų uždavimo technika, kompetentingi pokalbio vedejjai.

- Kandidatams žodžiu ir raštu teikiama informacija apie atrankos procedūrą.

- Vykdoma atrankos proceso stebèsena ir tobulinimas.

\section{Profesionalios darbuotojų atrankos tendencijos - atrankos metodų parinkimas}

Atrankos metodų parinkimas iš esmès priklauso nuo darbo ir organizacijos konteksto, kuriame atliekamas darbas. Atsirenkant metodus svarbu atsižvelgti i darbo pobūdị (darbo užduotis, atsakomybės lygị), vertinimą atliekančių specialistų 
kompetenciją, kandidatų skaičiu ir jų pasirengimą, metodų administravimo kaštus, turimus laiko ir finansinius išteklius ir kt.

Mokslininkai [26] atliko skirtingų atrankos metodų validumo tyrimu metaanalize, kuri parodè, kad struktūruoto pokalbio ir bendrųų kognityvinių gebejjimų testo derinys yra efektyviausias prognostinio validumo atžvilgiu $(0,63)$, t. y. tiksliausiai nuspèja būsimus darbo rezultatus. Valstybès tarnybos departamentas būtent ir pasirinko šių metodikų derinị.

Interviu - dažniausiai atrankose taikoma ịvertinimo priemonè. Interviu gali būti taikomas ir kaip vienintelè vadovų atrankos priemonè, kaip pagrindinis metodas ịvertinti kandidato žinias, ịgūdžius, asmenines savybes. Vadovų atrankoje dažniausiai taikomi nestruktūruoti arba pusiau struktūruoti interviu, o skirtinguose atrankos etapuose paprastai taikoma ir viena, ir kita. Interviu struktūravimo pasirinkimą lemia keletas faktorių: interviu tikslas, interviu vedejo profesionalumas, kokią vietą užima interviu visame atrankos procese: pirminis interviu, interviu prieš testavimą, interviu po testavimo, interviu įvertinimo centre ir kt. Struktūruotu interviu gali būti siekiama patikrinti kandidato biografinius duomenis ir patikslinti pagrindinius darbo biografijos faktus.

Valstybės tarnybos departamentas, tikrindamas pretendentų į vadovų pareigas vadovavimo gebėjimus, taiko pusiau struktūruotą interviu ir elgesio klausimus. Pusiau struktūruotas interviu ịpareigoja interviu vedẻją visiems kandidatams užduoti vienodus pagrindinius klausimus ir po kiekvieno interviu įvertinti konkrečias, visiems kandidatams vienodas ir su darbu susijusias kompetencijas. Be to, visiems kandidatams naudojamas tas pats interviu planas. Interviu vedejjas turi būti labai gerai pasiruošęs: mokèti vesti pokalbị, stebèti pašnekovo neverbalinius signalus ir ypatingai gerai sugebeti klausyti ir įvertinti, ką kalba kandidatas.

Kompetencijų vertinimo centras - tai kandidatų vertinimas taikant keletą metodų kiekvienai reikalingai kompetencijai įvertinti, priskiriant keletą vertintojų kiekvienam kandidatui. İvertinimo centro principai ir metodai užtikrina vertinimo visapusiškumą ir objektyvumą. Jị taikant galima patikimiau už pavienius metodus ịvertinti, kiek asmens turimi sugebèjimai bei potencialas atitinka darbuotojo veiklai keliamus reikalavimus. Taikant ịvertinimo centro metodą naudojamos grupinès užduotys, atvejo analizès ar kitos situacinès užduotys, testai, klausimynai, įvairiu formų individualūs pokalbiai. Atlikdami užduotis kandidatai turi galimybę parodyti ne tik turimas žinias, bet ir savo realius sugebejjimus. Ivvertinimo centro metodas suteikia galimybę ịvertinti kandidato elgesị situacijose, su kuriomis jis susidurs darbe, nepriklausomai nuo jo turimos patirties.

\section{Konkursą laimėjusių asmenų ir jų tiesioginių vadovų nuomonės apie naują atrankos ị valstybẻs tarnybą sistemą tyrimas}

Apklausa elektroniniu būdu buvo vykdoma nuo 2013 m. lapkričio 25 d. iki $2014 \mathrm{~m}$. gegužès $27 \mathrm{~d}$. Visiems vadovams, kurie įdarbino valstybės tarnautojus nuo 
2013 m. birželio 1 d. pagal naująją atrankos sistemą, praejus ne mažiau kaip 3 mènesiams nuo naujų valstybės tarnautojų darbo pradžios, buvo siunčiamas prašymas užpildyti anketą. Iš viso buvo išsiųstas 951 prašymas, apklausoje sutiko dalyvauti 168 vadovai (atsakomumas 17,66 proc.). Analogiški prašymai buvo išsiųsti visiems naujai priimtiems ir ne mažiau kaip 3 mèn. dirbantiems valstybès tarnautojams. Iš viso tyrime sutiko dalyvauti 247 nauji valstybès tarnautojai iš 951 (atsakomumas 25,97 proc.). Atsižvelgiant ị tai, kad apklausos formos pildymas nebuvo privalomas, o ị atvirus klausimus paprastai atsako mažiau respondentų nei ị uždarus [11], laikytina, kad pateikti atsakymai pakankamai reprezentuoja valstybès tarnautojų požiūrị i naujają atrankos sistemą ir suteikia vertingos informacijos [3; 25].

Visų respondentų buvo prašoma nurodyti po tris naujosios atrankos privalumus ir trūkumus lyginant su ankstesniąja atrankos sistema.

Analizuojant respondentų atsakymus matyti, kad naujoji atranka sulaukia daugiau teigiamų nei neigiamų atsiliepimų.

Naujai įdarbinti valstybės tarnautojai džiaugèsi 3 metus galiojančiais testų rezultatais, pvz., „Taupomos valstybès lèšos ir kandidatu bei konkurso organizatoriu laikas, nes išlaikytas bendruju gebejjimu testas galioja 3 metus ir nereikia pretenduojant $i$ kelias pareigas kelis kartus laikyti to paties testo“. Daugelis teigiamai ịvertino dalies atrankos procedūrų perkèlimą ị elektroninę erdvę - greičiau galima pateikti įstaigoms dokumentus, operatyviai sužinoma, ar pateikti visi reikalingi dokumentai ir ar pretendentas atitinka bendruosius ir specialiuosius reikalavimus. Elektroninė sistema užtikrina, $k a d$, ,ị konkursą registruojasi visi norintys, nebūna taip, kad „netyčia“ sužinai, kad konkursas baigèsi“, „,nebèra popierizmo“. Taip pat daugelis palankiai ịvertino galimybę užsiregistruoti testavimams norimame mieste ir norimu laiku. Bendrųjų gebejjimų testo kompiuterizavimas eliminuoja žmogiškosios klaidos, skaičiuojant rezultatus, tikimybę.

Daugelis respondentų mano, kad bendrųjų mąstymo gebëjimų ir kompetencijų tikrinimas yra geresnis atrankos metodas nei anksčiau buvęs teisès aktų testas. „Asmuo - dalyvis konkurse patikrinamas visapusiškai, gebejjimas mastyti, gebéjimas skaityti ir suvokti istatymus bei gebejimas bendrauti;“" sudaroma „galimybe parodyti savo sugebejimus spręsti problemas, priimti sprendimus."

Jie taip pat kaip privalumą minèjo tai, kad „,nebereikia mokytis mintinai teisès aktu, kurie konkrečiai pareigybei gali būti visai nereikalingi“, „,bendruju gebejjimu testui (tiek I, tiek II daliai) laikyti nereikia specialiai ruoštis". Naujo pobūdžio užduotys tapo „motyvacija potencialiems valstybès tarnautojams arba esamiems tobulinti savo kvalifikacija“".

Respondentai nurode tokius pasikeitusios atrankos įstaigose privalumus:

- „Yra pakankamai laiko pasiruošti pokalbiui“;

- „Pokalbiui komisijoje reikia ruoštis iš mažesnès apimties dokumentu, t. y. tik iš medžiagos, susijusios su konkrečia pareigybe“;

- „Pokalbio metu tikrinamos ne tik kandidato žinios, bet ir gebejjimas valdyti kritines situacijas, asmeninès savybès"; 
- „Ilgesnio pokalbio metu atsiskleidžia daugiau sugebëjimu“.

Apklausti naujų valstybės tarnautojų vadovai šalia jau išvardintų privalumų akcentavo mažesnius atrankos vykdymo kaštus - „taupomi institucijos žmogiškieji ištekliai ir ju laikas“. „Sumažéjo organizaciniu klausimu konkurso pasiruošimui“, „nebereikalinga klausimu sudarymo komisija, ju sudarymas užima daug papildomo laiko“. „Mažiau netiesioginiais reikalais apkraunami priimančios institucijos darbuotojai (ne personalo klausimais)"; , institucijai nereikia organizuoti testo laikymo procedūru (nereikia patalpu, testus laikančiuju priežiūros ir pan.“. Liberalizuota atrankos tvarka leidžia geriau panaudoti turimus resursus, „atranka galima daryti bet kokia diena, o esant daug pretendentu, - kelias dienas“. „Pačioje įstaigoje konkursa galima suspèti pravesti per viena dienq nors ir bütu daug pretendentu“.

Praktinių užduočių taikymas atrankos ịstaigoje metu ,padeda giliau ịžvelgti pretendentu vidines savybes, atskleisti tam tikrai sričiai reikalingus gebejjimus“.

Taip pat buvo atkreiptas dẻmesys ị profesionalų užsienio kalbų mokejjimo tikrinimą tų asmenų, kurie pretenduoja ị užsienio kalbų mokèjimo reikalaujančias pareigybes. Iki $2013 \mathrm{~m}$. birželio 1 d. užsienio kalbos žinias tikrindavo atrankos komisijos įstaigose.

Vadovų manymu, iš dalies centralizuota pretendentų į valstybės tarnybą atranka užtikrina, kad atrankoje ịstaigoje nebebus minimalios kompetencijos ar gebejjimų neturinčių žmonių, o patys pretendentai bus motyvuoti: ,„staigos apsisaugo nuo itin silpnų kandidatų - jie nepraeina bendrųjų gebejjimų testo“; , ,i atranką atvyksta tvirtai apsisprendę kandidatai, kad nori dirbti mūsų ịstaigoje“. Valstybės tarnybos departamente atliekamas vadovavimo gebejjimų tikrinimas užtikrina, kad vadovų konkursuose dalyvaus tik pakankamai žinių ir / ar patirties turintys asmenys.

Pagyrimo žodžių sulaukè ir testo pobūdis: ,gerai, kad tikrina loginị mastyma, sugebejima spręsti problemas kompleksiškai, kad klausimai yra ne „iškalami“, o turi būti išmąstomi“. „Iki 2013-06-01 galiojusi tvarka eilę metu buvo nusistovejjusi, pretendentai jau buvo „išmokę" 70 besikartojančiu klausimu, kurie büdavo pateikiami per konkursq ir tai nebūdavo tikroji atranka, o klausimu-atsakymu „,kalimas mintinai.“"

Daugiau nei ketvirtadalis vadovų (39 iš 145) ir daugiau nei pusé naujai priimtų valstybès tarnautojų (129 iš 247) pateikẻ apibendrintus naujosios atrankos vertinimus ir nurodè, kad ji yra skaidresne, objektyvesnè, aiškesnè, suprantamesné, paprastesnè, patogesnè, sąžiningesnè, sudaranti lygias galimybes, efektyvesnè, korektiškesnè, pagrịsta, užtikrintas didesnis viešumas.

Be abejo, kaip ir bet kokia diegiama naujovè, naujoji atrankos sistema sulaukè ir kritikos. Tiek naujai ịdarbinti valstybės tarnautojai, tiek jų vadovai atkreipé dèmesi i faktą, kad atrankos procedūra tapo ilgesnè, nei būdavo anksčiau. „Ilgas atrankos procesas, nes jei pretenduoji i konkursq, išsilaikai testa ir atitinki reikalavimus, dar nera rengiamas konkursas kol visi neišsilaiko testo ir pan. Kai kuriais atvejais labai ilgai užtrunka šis procesas ir krenta motyvacija laukti konkurso, kai nera informacijos, dèl ko jis dar nerengiamas ir pan.“ „Dabar yra trys dalys 
(bendrasis, vadovavimo testai ir pokalbis), kai anksčiau per viena diena viskas susitvarkydavo."

Dalis respondentų mano, kad atranka įstaigose vis dar stokoja skaidrumo: „antras atrankos etapas (t. y. vietoje) sudaro prielaidu piktnaudžiavimui taip pat, kaip ir buvo“; „galimas spaudimas palaikyti viena ar kita pretendenta išlieka ir naujoje atrankoje, todèl bütina tobulinti atrankos organizavima". Taip pat manoma, kad „Sistema būtu efektyvi, jei i kai kurias valstybès tarnautoju pareigas bütu pretendentu perteklius. Bet kai norinčiuju i šias pareigas nèra, tai ši sistema tik apsunkina pretendentu paieška.“.

Galiausiai nepasitenkinimą respondentams kelia centralizuoto bendrųų ir vadovavimo gebejjimų tikrinimo organizavimas. „Dél testo reikia važiuoti $i$ Vilniu, nes vietoje neorganizuojama, o jeigu organizuojama, tai nuolat nera vietu ar nèra kaip užsiregistruoti, kelionè reikalauja pakankamai daug išlaidu, nes ten reikia važiuoti tik dèl testo laikymo."

Akivaizdu, kad įdiegus naująją valstybės tarnautojų atrankos sistemą žengtas didelis žingsnis profesionalesnès valstybès tarnautojų atrankos link. Naujai ịdarbintų valstybės tarnautojų ir jų tiesioginių vadovų apklausa atskleidè, kad įvykdyti pokyčiai vertinami palankiai. Jų manymu, atranka yra skaidresné, objektyvesnè, paprastesnè, patogesnè - taigi, iš dalies buvo eliminuotos su ankstesne atranka susijusios ir mokslininkų [23] bei valstybinių institucijų [1] ịvardintos problemos. Tyrimai rodo, kad kandidatų reakcija ị atranką gali turèti įtakos kandidatų požiūriui ị organizaciją ir darbą, sprendimams dèl ịsidarbinimo ir rekomendavimo organizacijos kitiems, jų elgsenai ir nuostatoms atrankos metu ir jau prièmus ị darbą [31]. Tai tampa itin aktualu siekiant atsilaikyti konkurencinejje kovoje su privačiu sektoriumi bei laisvo darbo jègos judejjimo teikiamomis galimybèmis ir pritraukti gerus specialistus tarnauti valstybei.

Vis dar iššūkiu išlieka atrankos proceso skaidrumo užtikrinimas valstybės tarnautojus atrenkančiose ịstaigose. Igyvendinant valstybès tarnautojų atrankos sistemos reformą, daug dèmesio buvo skirta įstaigose atrankas atliekančių komisijos narių kvalifikacijai stiprinti, parengtos metodinès pokalbio vedimo, praktinių užduočių rengimo, pretendentų tinkamumo vertinimo rekomendacijos. Tačiau vis dar gajus pretendentų įsitikinimas, kad ị valstybès tarnybą patenka tik reikalingi asmenys, iš anksto žinantys klausimus, net jei patys konkursuose laimėjo sąžiningai.

Atsižvelgiant ị respondentų pasiūlymus bei ị planuojamą diegti kompetencijų modelị valstybès tarnyboje galvojama tobulinti bendrųjų gebejimų testo turinị ir struktūrą. Didžiausias pokytis būtų pretendentų diferencijavimas pagal testo rezultatus, $\mathfrak{i}$ kokio lygio pareigybes jie gali kandidatuoti. Tačiau nèra planuojama keisti testo laikymui skirto laiko, užduočių sudètingumo ar užduočių pateikimo sekos. Valstybès tarnybos departamento duomenimis [32], pretendentai bendrųjų gebėjimų testo laikymui vidutiniškai išnaudoja 75 proc. skirto laiko, o vidutinis teste surenkamas balas 20 proc. viršija reikalavimą teisingai atsakyti i 50 proc. pateiktų atskirų testų dalių klausimų, kad testas būtų laikomas išlaikytu [33]. 
Atrankos procedūros trukmès klausimas yra sèkmingai sprendžiamas didèjant pretendentų, išlaikiusių bendrųjų gebėjimų testą, skaičiui. Valstybės tarnybos departamento duomenimis, 2014 m. spalio 1 d. buvo daugiau nei 7600 asmenų, sèkmingai išlaikiusių testą ir galinčių aktyviai dalyvauti konkursuose bei pakaitinių valstybės tarnautojų atrankose. Atitinkamai daugèja konkursų, į kuriuos pretenduoja tik bendrųjų gebejjimų testą išlaikiusieji, kas patị atrankos procesą sutrumpina nuo teoriškai galimų 3 mènesių iki 2 savaičių. Kita vertus, atrankos procedūros trukmė Lietuvoje yra panaši ị kitų Europos šalių atrankų trukmę. Remiantis EPSO tyrimu [29], 10 Europos šalių (47 proc.) atranka trunka nuo 1 iki 2 mèn., 6 šalyse (29 proc.) - nuo 3 iki 4 mèn. O ir privačiame sektoriuje aukštesnès kvalifikacijos specialistų atranka trunka panašiai. Todèl įstaigos turètų kasmet atlikti darbuotojų poreikio analizę ir ruoštis potencialiai darbuotojų kaitai iš anksto.

Apibendrinant tyrimo rezultatus galima teigti, kad naujoji atrankos sistema padeda tvirtus pagrindus naujo požiūrio ị valstybès tarnybą ir valstybès tarnautojus formavimui, o tai gali tapti postūmiu ir visos valstybès tarnybos sistemos kaitai.

\section{Išvados}

1. Poreikis keisti valstybès tarnautojų atrankos sistemą kilo dèl vis didejjančio neatitikimo tarp reikalavimų, kuriuos kelia šiuolaikiniai šalies ekonomikos bei visuomenės procesų raidos pokyčiai, ir viešosios biurokratijos valdymo gebejjimų. Ypač tai išryškèjo 2008 metais prasidejjus ekonomikos krizei, kai prireikè greitų ir veiksmingų valstybės tarnybos pertvarkymo sprendimų. Penkioliktosios Lietuvos Respublikos Vyriausybès programoje bei 2010 metais patvirtintoje Valstybès tarnybos tobulinimo koncepcijoje aiškiai pasisakoma už naujosios viešosios vadybos principų taikymą žmogiškųjų išteklių valdyme.

2. Nors naujosios viešosios vadybos doktrina nedviprasmiškai teigia, kad ịstaigų vadovams reiktų suteikti kiek įmanoma didesnę veiksmų ir sprendimų laisvę, valstybės tarnautojų atrankos pirmąji etapą - bendrųjų ir vadovavimo gebėjimų testavimą, buvo nuspręsta leisti vykdyti centralizuotai, pavedant tai atlikti Valstybès tarnybos departamentui. Toks iš dalies centralizuotos atrankos modelis yra įdiegtas Austrijoje, Prancūzijoje, Rumunijoje, Didžiojoje Britanijoje, Vengrijoje ir kitose šalyse. Antrasis atrankos etapas vykdomas pačioje istaigoje ir yra decentralizuotas.

3. Žmogiškųjų išteklių vadybos požiūriu bendrųjų gebėjimų testai sudaro sąlygas atrinkti asmenis, kurie sėkmingai ir greitai sprendžia problemas, tinkamai reaguoja į naujas ir sudėtingas situacijas. Tuo tarpu vadovavimo gebejjimų tikrinimas igalina pasirikti pretendentus, kurie geba planuoti ir organizuoti jam patikètos žmonių grupės darbą. Tokiu būdu naujieji atrankos principai leidžia atrinkti tinkamus pretendentus ị valstybės tarnybą ir padidinti valstybės tarnybos lankstumą, veiklos efektyvumą ir valdymo kokybę. 
4. Kaip rodo 2013-2014 metais atliktos vadovų, įdarbinusių darbuotojus pagal naująją tvarką, ir darbuotojų priimtų pagal naująją atrankos tvarką, apklausos duomenų analizè, įdiegta iš dalies centralizuota valstybès tarnautojų atrankos sistema užtikrina efektyvų ir skaidrų asmenų priėmimą į valstybės tarnautojų pareigas. Respondentai teigiamai vertina bendrujų gebẻjimų testų bei vadovavimo gebėjimų tikrinimo metodiką ir procedūras, kurios leidžia atrinkti tinkamesnius kandidatus ị valstybès tarnybą. Respondentų nuomone, atrankos proceso perkèlimas ị elektroninę erdvę ir dokumentų pateikimas įstaigoms bei testo laikymas kompiuteryje didina atrankos procedūrų skaidrumą. Parengtas praktinis vadovas atrankos komisijoms, kuriame pateikta profesionalios atrankos vykdymo (pokalbio ir praktinių užduočių rengimo) metodika bei šios metodikos taikymo praktikoje apmokyti valstybės institucijų vadovai ir personalo specialistai leidžia profesionaliai atlikti atranką.

5. Naujojo atrankų modelio taikymas prisidejjo prie vieno iš svarbiausių valstybės tarnybos modernizavimo tikslų - žmogiškųjų išteklių valdymo skaidrumo didinimo ir protekcionizmo bei nepotizmo apraiškų mažinimo. İdiegus kompiuterinị testavimą ir vadovavimo gebejjimų patikrinimą, kurị Valstybès tarnybos departamente atlieka psichologai / atrankų ekspertai, prièmimas ị valstybės tarnautojo pareigas tapo mažiau priklausomas nuo subjektyvių žmogiškųjų faktorių įtakos.

\section{Literatūra}

1. $2011 \mathrm{~m}$. Lietuvos korupcijos žemėlapis. http://www.stt.lt/documents/soc_tyrimai/ Korupcijos_zemelapis.pdf [2014-09-14].

2. Armstrong, M. Amstrongs's Handbook of Human Resource Management Practice. Kogan Page, 2009. 3.

3. Barrack, M., Feild, H. S., and Gatewood, R. D. Selection in Human Resource Management. South-Western/Cengage Learning, 2011.

4. Bauer, T. N., McCarthy, J., Anderson, N., Truxillo, D. M., and Salgado, J. F. What We Know about Applicant Reactions to Selection: Research Summary and Best Practices. Society for Industrial and Organizational Psychology, Inc., 2012. http://www.siop.org/ WhitePapers/White Paper Series 20112012. ApplicantReactions.pdf [2014-10-02].

5. Bertua, C., Anderson, N., and Salgado, J. F. The Predictive Validity of Cognitive Ability Tests: A UK Meta-Analysis. Journal of Occupational and Organizational Psychology, 2005, vol. 78, Issue 3, 387-409.

6. Dessler, G. Human Resource Management. 2011, Pearson.

7. Donahue, J., Routch, K., and Thomas, N. Strengthening the Middle: Global Challenges and Best Practices in Mid-level Leader Assessment and Development. Development Dimensions International, Inc., MMXI, 1-24 www.ddiworld.com/DDIWorld/media/ trend-research/strengthening-the-middle_tr_ddi.pdf [2014-09-25]

8. Geer, J. G. Do Open-ended Questions Measure „Salient“ Issues? Public Opinion Quarterly. 1991, Vol. 55, 360-370.

9. Hausknecht, J., Day, D. V., and Thomas S. C. Applicant Reactions to Selection Procedures: An Updated Model and Meta-Analysis. Personnel Psychology, 2004, vol. 57, No. 3, 639-683. 
10. Hègelis G. Teisès filosofijos apmatai. Vert. Anilionytė L. ALK Vilnius: Mintis, 2000.

11. Krosnick, J. Survey Research. Annual Review of Psychology, 1999, Vol. 50, 537-567.

12. Lehkonen, S. EPSO Benchmarking Survey 2013. Presentation at Informal Meeting of EUPAN Directors General and TUNED in Vilnius on 6th December 2013.

13. Leonas P. Teisès filosofijos istorija. Vilnius: Mintis, 1995.

14. Lietuvos Respublikos Vyriausybès 2006-2008 metų programos igyvendinimo priemonès. Valstybės žinios, 2006, Nr. 112-4273. www.lrvk.lt/bylos/vyriausybes/14vyr-dok/n1020_priemones.pdf [2014-09-29].

15. Lofgren, C. A. Validity Evidence of a Multiple-Choice Test and a Performance Test in an Employment Setting. Doctoral Dissertation, University of Pittsburgh, 2005, 1-179. http://d-scholarship.pitt.edu/9909/ [2014-09-29].

16. Lukaszewski, K. M., Dickter, D. N., Lyons, B. D., and Kehoe, J. F. Recruitment and Selection in an Internet Context. In Kavanagh, M. J., Thite, M. (Eds.). Human Resource Information Systems: Basics, Applications, and Future Directions, 2009, Thousand Oaks, CA: Sage, 277-306.

17. Measuring the Quality of Government and Subnational Variation. Report for the European Commission Directorate-General Regional Policy. Directorate Policy Development. University of Gothenburg. 2010.

18. Nakrošis V. Viešojo valdymo reformos Lietuvoje: kodèl ir kuo reikia pakeisti naująą viešąją vadybą? Politologija, 2011, Nr. 61, 65-98.

19. Noe, R. A. Hollenbeck, J. R., Gerhart, B. and Wright, P. Human Resource Management: Gaining a Competitive Advantage. McGraw-Hill/Irwin, 2010.

20. Osborne D., and Gaebler T. Reinventing Government. How the Entrepreneurial Spirit is Transforming Public Sector. Reading, M: Addison-Wesley Publishing Company. 1992.

21. Peters, G. Four Main Administrative Traditions. World Bank. Administrative \& Civil Service Reform.

22. Peters, G. Four Main Administrative Traditions. World Bank. Administrative \& Civil Service Reform. http://web.worldbank.org/WBSITE/EXTERNAL/TOPICS/EXTPU BLICSECTORANDGOVERNANCE/0,,contentMDK:20134002 pagePK:210058 pi PK:210062 theSitePK:286305,00.html [2014-10-02].

23. Pivoras S. Konkursinès atrankos i Lietuvos valstybès tarnybą tobulinimas gero valdymo iššūkių perspektyvoje. Viešoji politika ir administravimas, 2012, T. 11, Nr. 3, 473-487.

24. Pulakos, E. D. Selection assessment methods: A guide to implementing formal assessments to build a high-quality workforce. 2005, Alexandria, VA: Society for Human Resources Management.

25. Sacks, D. Survey Response Rates. http://www.surveygizmo.com/survey-blog/surveyresponse-rates/ [2014-09-28].

26. Schmidt, F. L., and Hunter, J. E. The Validity and Utility of Selection Methods in Personnel Psychology: Practical and Theoretical Implications of 85 Years of Research Findings. Psychological Bulletin, 1998, Vol. 124, 262-274.

27. Scilly, M. The Disadvantages of a Centralized Recruitment Process. http:// smallbusiness.chron.com/disadvantages-centralized-recruitment-process-12261.html [2014-09-21]. 
28. Stankevičienė S., Vijeikienė I., Vijeikis D., Žemaitis V., Židonis Ž., Stankevičienė L., Misevičienė R., Žemaitienė R. Valstybès tarnautojų atrankos tobulinimo koncepcija, 2013, 1-251.

29. Thematic Paper Series: Reforms in Selection / Recruitment of Human Resources. Lithuanian Presidency of EUPAN June 2013 - January 2014. http://www.eupan.eu/ files/repository/2013121685729_Thematic_Papers_Series_LT_Presidency.pdf [201409-29].

30. Valstybės tarnybos departamento 2014-08-21 pažyma Nr. 27L-719 „Dèl apklausos apie valstybės tarnybos santykių reglamentavimo praktinio įgyvendinimo rezultatų“"

31. Valstybės tarnybos departamento 2014-07-04 pažyma Nr. 27 L-587 „Dèl bendrųju gebèjimų testo optimalios trukmès“.

32. Valstybès tarnybos departamento 2014-05-08 pažyma Nr. 27L-432 „Dèl bendrųjų gebejjimų testo sunkumo“.

33. Valstybès tarnybos departamento 2014-07-04 pažyma Nr. 27 L-588 „Dèl pretendentų skaičiaus konkursuose ir pakaitinio valstybės tarnautojo atrankose“.

\section{Rasa Tumėnè, Irena Žukauskaite, Žilvinas Židonis}

\section{The New System of Civil Service Selection: First Results and Insights}

\section{Abstract}

Numerous academic studies and reports have emphasized that only with transparent and professional civil service a country can be able to benefit from the processes of economic growth and social development. The factor of "input", i.e., civil service personnel selection and recruitment, plays a crucial role. Civil service personnel recruitment in Lithuania was based on legalistic model of public bureaucracy. However, in face of new economic and social challenges, the model turned out as inefficient, lacking of transparency and flexibility. Therefore, a new concept of civil service recruitment was introduced in 2013. In contrast to legalistic approach, the new recruitment model was influenced by ideas of New Public Management, emphasizing the importance of general and managerial competences. The survey conducted in November 2013 - May 2014 showed that Lithuanian civil servants evaluated the new system as more transparent, efficient and flexible, compared to the old one.

Rasa Tumènè - Valstybės tarnybos departamento Atrankų skyriaus vedėja.

E. paštas: rasa.tumene@vrm.lt

Irena Žukauskaite - Valstybės tarnybos departamento Testavimo grupės testų eksperte், socialinių mokslų daktarè.

E. paštas: irena.zukauskaite@vrm.lt

Žilvinas Židonis - Mykolo Romerio universiteto Politikos ir vadybos fakulteto Viešojo administravimo instituto docentas, socialinių mokslų daktaras.

E. paštas: zzidonis@mruni.eu

Rasa Tumene, Head of Selection Division at Civil Service Department

E-mail: rasa.tumene@vrm.lt 
Irena Žukauskaité, Doctor of Social Sciences, Expert of Testing at Civil Service Department Testing Group

E-mail: irena.zukauskaite@vrm.1t

Žilvinas Židonis, Doctor of Social Sciences, Mykolas Romers University, Faculty of Politics and Management, Institute of Public Administration, Associate Professor.

E-mail: zzidonis@mruni.eu

Straipsnis įteiktas redakcijai 2014 m. liepos mėn.; recenzuotas; parengtas spausdinti lapkričio mèn. 